\title{
Cardiotrophin-1, a Muscle-Derived Cytokine, Is Required for the Survival of Subpopulations of Developing Motoneurons
}

\author{
Ronald W. Oppenheim, ${ }^{1}$ Stefan Wiese, ${ }^{4}$ David Prevette, ${ }^{1}$ Mark Armanini, ${ }^{2}$ Siwei Wang, ${ }^{1}$ Lucien J. Houenou, ${ }^{1}$ \\ Bettina Holtmann, ${ }^{4}$ Rudolf Götz, ${ }^{4}$ Diane Pennica, ${ }^{3}$ and Michael Sendtner ${ }^{4}$ \\ 1 Department of Neurobiology and Anatomy and the Neuroscience Program, Wake Forest University School of Medicine, \\ Winston-Salem, North Carolina 27157, Departments of ${ }^{2}$ Cell Biology and Technology and ${ }^{3}$ Molecular Oncology, \\ Genentech, South San Francisco, California 94080, and 4 Klinische Forschergruppe Neuroregeneration, Department of \\ Neurology, University of Wuerzburg, 97080 Wuerzburg, Germany
}

\begin{abstract}
Developing motoneurons require trophic support from their target, the skeletal muscle. Despite a large number of neurotrophic molecules with survival-promoting activity for isolated embryonic motoneurons, those factors that are required for motoneuron survival during development are still not known. Cytokines of the ciliary neurotrophic factor (CNTF)-leukemia inhibitory factor (LIF) family have been shown to play a role in motoneuron (MN) survival. Importantly, in mice lacking the LIFR $\beta$ or the CNTFR $\alpha$ there is a significant loss of MNs during embryonic development. Because genetic deletion of either (or both) CNTF or LIF fails, by contrast, to perturb MN survival before birth, it was concluded that another ligand exists that is functionally inactivated in the receptor deleted mice, resulting in $\mathrm{MN}$ loss during development. One possible candidate for this ligand is the CNTF-LIF family member cardiotrophin-1 (CT-1). CT-1 is highly expressed in
\end{abstract}

Beginning with the demonstration that developing motoneurons (MNs) depend on muscle-derived proteins for their survival (Calof and Reichardt, 1984; Dohrmann et al., 1986; Oppenheim et al., 1988; Arakawa et al., 1990), a large number of putative neurotrophic factors from several different gene families have been identified and shown to promote MN survival both in vitro and in vivo (Henderson, 1996; Oppenheim, 1996a). One of the striking conclusions from all these studies is that no single factor, even when given at optimal doses, supports $>20-30 \%$ of the total number of MNs that undergo normal programmed cell death (PCD). Because treatment with combinations of two or more factors increases MN survival considerably (Arakawa et al., 1990; Hughes et al., 1993; Arce et al., 1998; Hanson et al., 1998), it has been proposed that (1) individual MNs may require multiple factors for optimal survival and (2) subpopulations of MNs may differ in their trophic requirements based on their stage of maturation, peripheral targets (e.g., limb vs nonlimb or between specific muscles), afferent inputs, or functional properties (Oppenheim, 1996b). For example, limb versus nonlimb innervating

Received Aug. 31, 2000; revised Oct. 26, 2000; accepted Nov. 14, 2000.

This work was supported by grants from the Human Frontier Science Program Organization, the Deutsche Forschungsgemeinschaft (To61/8-4), and the Bundesministerium für Bildung, Wissenschaft, Forschung und Technologie (01KO9705) (M.S.), by National Institutes of Health Grants NS20402 and NS36945 (R.W.O.), and a Muscular Dystrophy Association grant (L.J.H.). We thank J. Kara, M. Pfister, and T. Swanson for excellent technical assistance. We are also indebted to M. Moore for helping in generating the CT-1 KO mice and W. Wood for helpful discussions during the course of this work.

Correspondence should be addressed to Michael Sendtner, Klinische Forschergruppe Neuroregeneration, Department of Neurology, University of Wuerzburg, JosefSchneider-Strasse 11, 97080 Wuerzburg, Germany. E-mail: sendtner@mail.uniwuerzburg.de.

Copyright (C) 2001 Society for Neuroscience $\quad 0270-6474 / 01 / 211283-09 \$ 15.00 / 0$ embryonic skeletal muscle, secreted by myotubes, and promotes the survival of cultured embryonic mouse and rat MNs. Here we show that $c t-1$ deficiency causes increased motoneuron cell death in spinal cord and brainstem nuclei of mice during a period between embryonic day 14 and the first postnatal week. Interestingly, no further loss was detectable during the subsequent postnatal period, and nerve lesion in young adult ct-1-deficient mice did not result in significant additional loss of motoneurons, as had been previously observed in mice lacking both CNTF and LIF. CT-1 is the first bona fide musclederived neurotrophic factor to be identified that is required for the survival of subgroups of developing motoneurons.

Key words: programmed cell death; spinal cord; CNTF; LIF; facial motoneurons; axotomy

MNs require hepatocyte growth factor (HGF)-scatter factor (SF) for their survival (Ebens et al., 1996; Yamamoto et al., 1997; Novak et al., 2000). In the chick, brain-derived neurotrophic factor (BDNF) selectively promotes MN survival only during the last half of the normal period of PCD (McKay et al., 1996; Becker et al., 1998), and glial cell line-derived neurotrophic factor (GDNF) is required for the survival of distinct subpopulations of MNs defined by their pattern of receptor expression and location in the spinal cord (Garcés et al., 2000; Oppenheim et al., 2000).

Members of the ciliary neurotrophic factor (CNTF)-leukemia inhibitory factor (LIF)-cardiotrophin-1 (CT-1) family support motoneuron survival (Arakawa et al., 1990; Sendtner et al., 1990; Oppenheim et al., 1991; Henderson et al., 1994) by acting through receptors involving LIFR $\beta$ and gp130. Genetic deletion of either LIFR $\beta$ (Li et al., 1995), gp130 (Nakashima et al., 1999), or the CNTFR $\alpha$ (DeChiara et al., 1995) results in significant MN loss in mouse embryos, in contrast to deletion of CNTF and/or LIF (Stewart et al., 1992; Escary et al., 1993; Masu et al., 1993; Sendtner et al., 1996). These data suggest that CT-1 is a likely candidate trophic factor required for the survival of the subpopulations of MNs lost in LIFR $\beta$ and gp130-deficient mice. However, CT-1 fails to bind to CNTFR $\alpha$ (Pennica et al., 1996; Robledo et al., 1997; Arce et al., 1999), indicating that yet another unknown CNTF-LIF family member is involved in the MN loss in CNTFR $\alpha$-deficient mice.

To further characterize the role of CT-1 in MN survival, we have examined: (1) the effects of CT-1 on cultured chick and mouse MNs; (2) the effects of CT-1 treatment on the in ovo survival of chick MNs and the in utero survival of mouse MNs; and (3) the survival of MNs in mice-deficient in CT-1. The results from all three approaches 

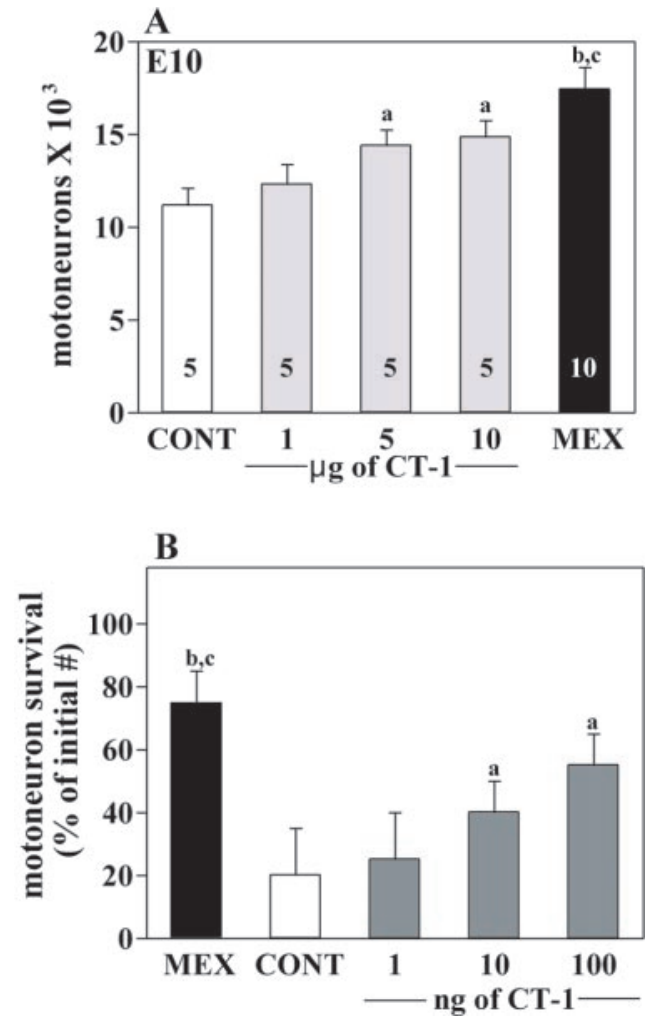

Figure 1. The effects of CT-1 on the survival of developing chick embryo motoneurons in vivo $(A)$ and in vitro $(B)$. $A$, CT-1 treatment has a modest but significant dose-dependent effect on MN survival in vivo. ${ }^{a} p<0.01$ versus CONT; ${ }^{\mathrm{b}} p<0.001$ versus CONT; ${ }^{\mathrm{c}} p<0.01$ versus 5 or $10 \mu \mathrm{g}$ of CT-1. Numbers in bars represent number of observations. $B$, Survival of lumbar MNs in vitro after treatment with CT-1 for $48 \mathrm{hr}$. ${ }^{\mathrm{a}} p<0.01$ versus CONT; ${ }^{\mathrm{b}} p<0.005$ versus CONT; ${ }^{\mathrm{c}} p<0.02$ versus 10 or $100 \mathrm{ng}$.

support a physiological role for CT-1 in the survival of subpopulations of developing MNs.

\section{MATERIALS AND METHODS}

Materials. Recombinant human leukemia-inhibitory factor (rhLIF) and recombinant CT-1 were obtained from Calbiochem (Bad Soden, Germany) or produced by Genentech and provided by D. Pennica. Recombinant rat CNTF was prepared and purified from Escherichia coli in our lab as described (Masiakowski et al., 1991). Neurobasal medium, glutamax, HBSS, and trypsin were obtained from Life Technologies (Eggenstein, Germany). Horse serum was obtained from Linaris (Wertheim, Germany), apotransferrin and other fine chemicals from Sigma (Deisenhofen, Germany), and metrizamide from Boehringer Ingelheim Bioproducts (Heidelberg, Germany).

Homologous recombination of the CT-1 gene. A mouse genomic clone spanning a region of $16 \mathrm{~kb}$ between 2 SalI restriction sites covering the complete $c t-1$ gene was isolated from a lambda FIX II library. A $1 \mathrm{~kb}$ fragment between $N o t \mathrm{I}$ and $E c o$ RI containing exon 1 of the $c t-1$ gene was isolated and cloned $5^{\prime}$ from a neoR cassette into a Bluescript vector. Another $6.1 \mathrm{~kb}$ fragment SfiI to EcoRV covering the $3^{\prime}$ end of the $c t-1$ gene was connected $3^{\prime}$ to the neoR cassette. After linearization with XhoI, the resulting DNA fragment was electroporated into embryonic stem cells, and mice with homologous recombination of the $c t-1$ gene were obtained by established techniques.

Homologous recombination in offspring of these mice was tested by Southern blot analysis after digestion of mouse tail DNA with EcoRI and XhoI. For the wild-type gene, this resulted in a band of $15 \mathrm{~kb}$, for the recombined gene in a band of $12 \mathrm{~kb}$. A $1.2 \mathrm{~kb} X b a \mathrm{I}-\mathrm{XhoI}$ fragment was used as a probe.

The recombination of the $c t-1$ gene results in a deletion of a region spanning exon 2 and the complete coding region of exon 3.

Histological procedures and neuronal counts. The brains and spinal cords were prepared from mice that were perfused with $4 \%$ freshly prepared paraformaldehyde or dissected and immersion-fixed in either Bouins or
Table 1. In utero treatment with CT-1 on E14 leads to enhanced survival of lumbar motoneurons in vivo

\begin{tabular}{lll} 
Age & Control (saline treatment) & CT-1 \\
\hline E18.5 & $1440 \pm 236(n=8)$ & $1965 \pm 173(n=8)^{*}$ \\
\hline
\end{tabular}

${ }^{*} p<0.01, t$ test.

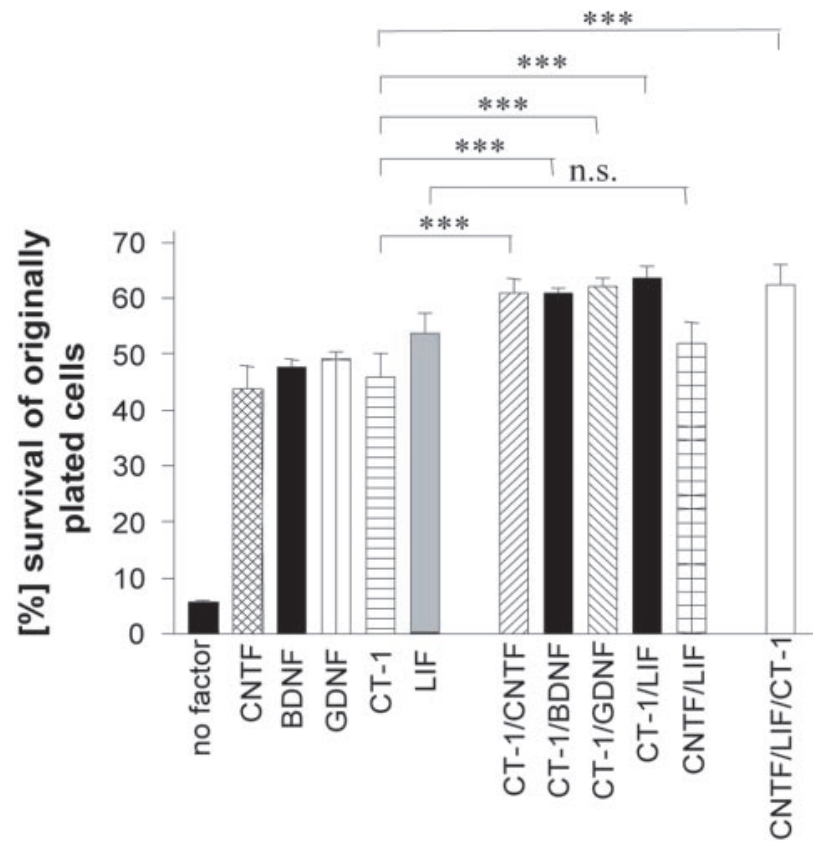

Figure 2. Cardiotrophin supports subpopulations of embryonic mouse lumbar spinal motoneurons. Survival of isolated motoneurons from E14 mouse lumbar spinal cord after $5 \mathrm{~d}$ in culture without or with neurotrophic factors. GDNF and BDNF were added at $1 \mathrm{ng} / \mathrm{ml}, \mathrm{CNTF}$, and CT- 1 at $10 \mathrm{ng} / \mathrm{ml}$. Addition of the combinations CT-1 and GDNF, CT-1 and BDNF, or CT-1 and CNTF supported significantly more motoneurons than CT-1 alone $\left({ }^{* * *} p<0.001\right.$, ANOVA).

Carnoys solution, processed, paraffin-embedded, sectioned serially (7-10 $\mu \mathrm{m})$, and stained with either thionin, cresyl violet, or hematoxylin and eosin. Motoneurons were counted in every 5 th or 10th section through each population examined, and the totals were multiplied by 5 or 10 to give an estimate of total cell numbers. Cell counts were done blind as to the treatment condition of the embryo-postnatal animals (control vs experimental) using a well established method that effectively eliminates the possibility of counting the same cell (healthy or pyknotic) twice (Clarke and Oppenheim, 1995). In the thoracic region MNs were only counted in one segment (T2), identified by adjacent DRG, whereas the entire brachial, lumbar, and cranial motor nuclei were counted. For assessing sensory neurons, cells in every $5^{\text {th }}$ section of the $4^{\text {th }}$ lumbar (L4) dorsal root ganglion (DRG) were counted. Cranial MNs in the facial and hypoglossal motor nuclei were also assessed quantitatively as described above.

In-situ hybridization of ct-1 wild-type and knock-out mice. Ct-1 wild-type and knock-out E13.5 mouse embryos were immersion-fixed overnight at $4^{\circ} \mathrm{C}$ in $4 \%$ paraformaldehyde, then cryoprotected overnight in $15 \%$ sucrose. Embryos were embedded in OCT (catalog \#4583; Tissue-Tek), frozen in liquid nitrogen, and sectioned at a thickness of $16 \mu \mathrm{m}$. Sections were processed for in situ hybridization for CT-1 by a modification of a method previously described by Phillips et al. (1990). ${ }^{33}$ P-UTP labeled RNA probes were generated as described by Melton et al. (1984).

Simultaneous hybridization with two probes to different regions of CT-1 mRNA was performed. The pair of sense and antisense probes were synthesized from a 161 and 188 DNA fragment [nucleotides 20-180 and 645-832, respectively (Pennica et al., 1995)] using T7 polymerase.

In utero treatment with CT-1. BALB/c ByJ mice (The Jackson Laboratory, Bar Harbor, ME) were bred at the Medical School animal facility at Wake Forest University. On gestation day 14.5 [the morning a vaginal plug was observed is designated embryonic day 0.5 (EO.5)], pregnant females were anesthetized with ether, and partial laparotomy was performed under sterile 
A
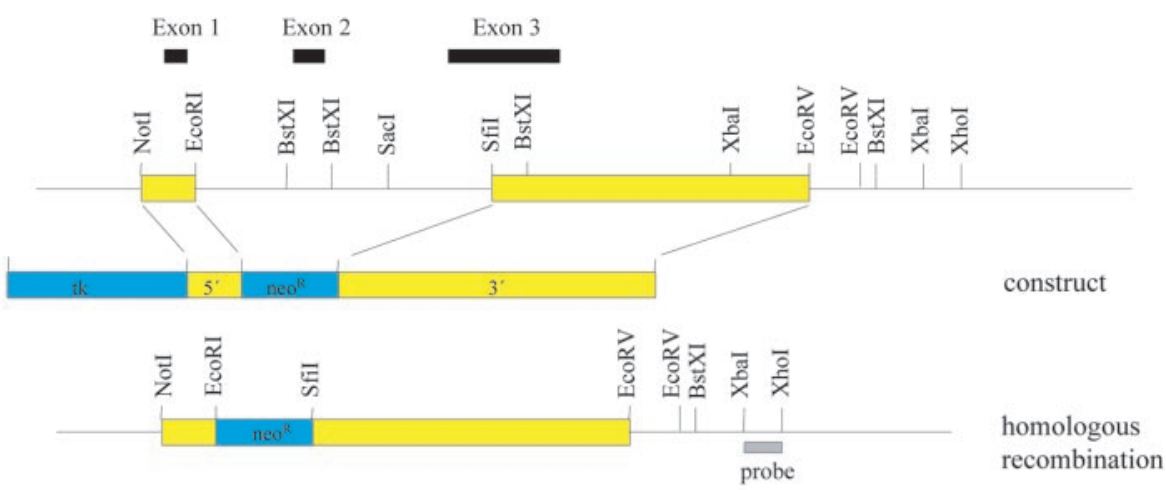

B
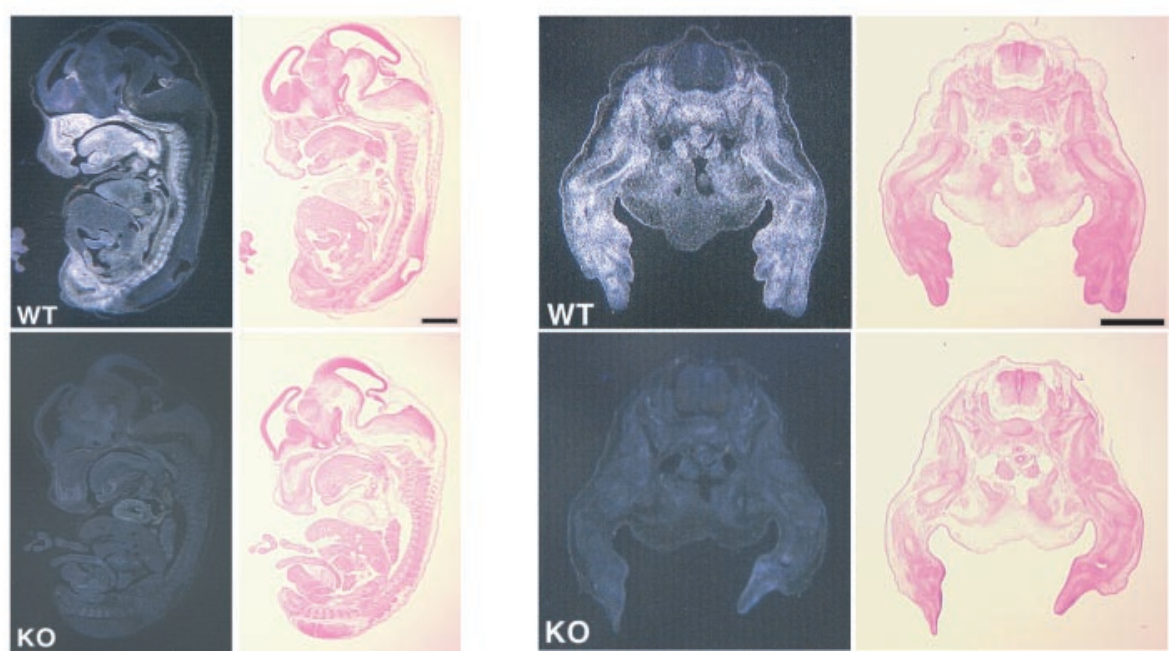

Figure 3. Gene knock-out of cardiotrophin-1 (ct-1) in mice. A, Map of the construct made for gene inactivation of $c t-1 . B, \mathrm{CT}-1$ in situ hybridization of sagittal and transverse sections of E13.5 wild-type and $c t-1 \mathrm{KO}$ mice. CT-1 is expressed at significant levels in myotubes but not in spinal cord. A mixture of probes covering exon 1 and 2 and a 3'untranslated region of the $c t-1$ gene (Pennica et al., 1996) that is deleted by the homologous recombination event and showed that mice homozygous for this mutation did not express CT-1 mRNA in a form that could be recognized by these probes, indicating that no CT-1 protein was produced in these mice. Scale bars, $1 \mathrm{~mm}$. conditions. One uterus (three to five embryos) was exposed, and each embryo injected with $5 \mu \mathrm{g}$ of CT-1 in 5 or $10 \mu \mathrm{l}$ of saline $(0.9 \% \mathrm{NaCl}, \mathrm{pH} 7.2)$ using a modified $10 \mu \mathrm{l}$ gauge Hamilton microsyringe, as described previously (Houenou et al., 1994). Injections were made into the amniotic fluid, embryos were replaced in the uterus, and the mother was allowed to recover after the abdomen was sutured. Fetuses from the contralateral uterus were used as controls (saline only). On E18.5, mice were killed with an overdose of ether, and fetuses were collected by cesarean section. Spinal cords from control and trophic factor- or saline-treated embryos were dissected out, fixed in Carnoys or Bouins solutions, and processed and counted as described above.

Chick motoneuron cultures. Motoneurons were isolated by the metrizamide gradient method of Bloch-Gallego et al. (1991). Briefly, spinal cords were dissected from E5.0 chickens, incubated in trypsin (0.2\% PBS), and dissociated by several passages through a $1.0 \mathrm{ml}$ blue pipette tip. Dissociated cells were layered onto $6.8 \%$ metrizamide layer and centrif uged at $1600 \mathrm{rpm}$ for $15 \mathrm{~min}$. The cell layer and the interface, containing predominantly large motoneurons, were collected and centrifuged for $10 \mathrm{~min}$ after being placed on $4 \%$ BSA cushion. The cell pellet was resuspended and plated in four-well Greiner dishes (Nunc, Roskilde, Denmark) previously treated with polyornithine $(1 \mu \mathrm{g} / \mathrm{ml}$; Sigma) and laminin $(20 \mu \mathrm{g} / \mathrm{ml}$; Life Technologies). A serum-free culture medium containing Leibovitz's L15 media (Life Technologies) supplemented with sodium bicarbonate $(625 \mu \mathrm{g} / \mathrm{ml}$, glucose $20 \mathrm{~mm})$, progesterone $\left(2 \times 10^{-8} \mathrm{M}\right.$; Sigma), sodium selenite $\left(3 \times 10^{-8} \mathrm{M}\right.$; Sigma), conalbumin $(0.1 \mathrm{mg} / \mathrm{ml}$; Sigma $)$, putrescine $\left(10^{-4} \mathrm{M}\right.$; Sigma), insulin (5 $\mu \mathrm{g} / \mathrm{ml}$; Sigma), and penicillin-streptomycin (Life Technologies) was used. Unless otherwise noted, $1 \mathrm{ml}$ of complete L15 media, with or without muscle extract ( $20 \mu \mathrm{g} / \mathrm{ml}$; prepared as previously described) or CT-1 was added to the tissue culture wells that were then seeded with cells $\left(2 \times 10^{4} /\right.$ well $)$. Cultures were incubated in $5 \% \mathrm{CO}_{2}$ incubator at $37^{\circ} \mathrm{C}$ with saturated humidity.

For experiments in which immunolabeled MNs were counted, cells were cultured on $10 \mathrm{~mm}$ round glass coverslips (Fisher Scientific, Houston, TX) treated as described above. Cells were first fixed with $10 \%$ formaldehyde in PBS, then incubated with monoclonal antibody to the gene product of the homeobox gene Islet-1, an early marker of developing motoneurons (Ericson et al., 1992) (1:250 in PBS; anti-Islet-1 was provided by Tom Jessell) for
1.5-2.0 hr at $37^{\circ} \mathrm{C}$. Coverslips were extensively washed with PBS and mounted with gel-mount (Biomed Instruments, Fullerton, CA). As a control, the primary antibody was omitted, and cells were fixed and incubated with the fluorescein-labeled secondary antibody only, which resulted in no specific labeling. MNs were counted in five predetermined $40 \times$ objective fields. Only viable MNs were considered. Motoneurons were identified as cells that were Islet-1 immunopositive, and cells were considered viable if their nuclei had a uniform appearance (i.e., no condensed chromatin). As reported previously (Milligan et al., 1994), between 70 and $85 \%$ of the cells were immunopositive for Islet-1 at 2-4 hr after plating, confirming that the cultures were greatly enriched for MNs. MN survival after $48 \mathrm{hr}$ is expressed relative to the number of Islet-1-positive cells present at the time of plating. The data presented represent the results of four independent replications using MEX and CT-1.

Mouse embryonic motoneuron cultures. Cultures of spinal motoneurons from embryonic day 14 mice were prepared by a metrizamide cushion centrifugation technique (Schnaar and Schaffner, 1981; Wiese et al., 1999). The ventrolateral parts of the lumbar spinal cords were dissected and transferred to HBSS containing $10 \mu \mathrm{M} 2$-mercaptoethanol. After treatment with trypsin $(0.05 \%, 10 \mathrm{~min})$, tissues were triturated, and the cell suspension was passed through a nylon mesh (100 $\mu \mathrm{m}$ pore size). The cells were overlaid on $10 \%$ metrizamide in HBSS. The metrizamide cushion was centrif uged for 20 min at $400 \times g$, and cells from the interface were taken out and transferred to culture medium without apotransferrin. Cells were plated at a density of $2000 \mathrm{cells} / \mathrm{cm}^{2}$ in four-well culture dishes (Greiner, Nürtingen, Germany), precoated with polyornithine and laminin as described (Arakawa et al., 1990). Cells were grown in neurobasal medium (Life Technologies) with serum and $500 \mu \mathrm{M}$ glutamax and $50 \mu \mathrm{g} / \mathrm{ml}$ apotransferrin at $37^{\circ} \mathrm{C}$ in a $5 \%$ $\mathrm{CO}_{2}$ atmosphere. Fifty percent of the medium was replaced at day 1 and then every second day. Neurotrophic factors were added at a concentration of 1 $\mathrm{ng} / \mathrm{ml}$. Culture medium was changed, and neurotrophic factors were freshly added on days 1, 3, and 5. Initial counting of plated cells was performed when all cells had attached to the bottom of the well after $4 \mathrm{hr}$ in culture. Phase-bright cells were counted at day 1 and then every second day until day 5. A total of 10 fields $\left(1.16 \mathrm{~mm}^{2} /\right.$ field $)$ were counted in each well at each time point. 


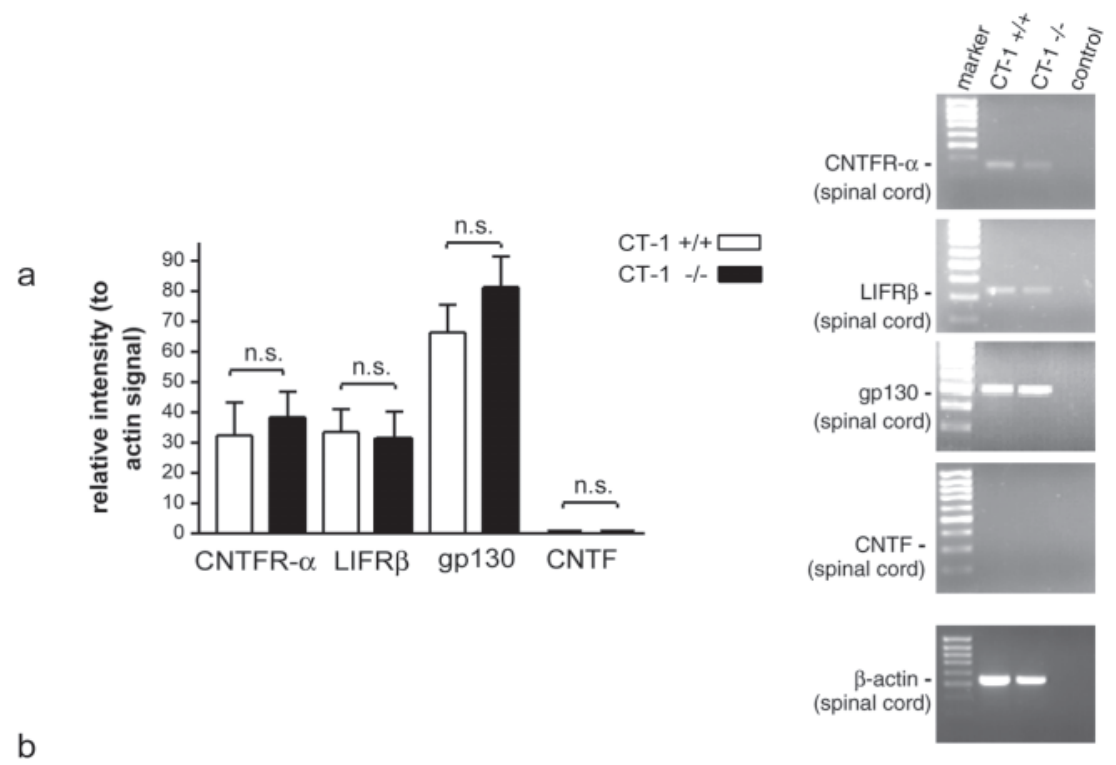

Figure 4. Analysis of expression of, CNTFR-LIFR $\beta$, gp130, CNTF, and LIF, in CT- $1+/+$ and CT- $1-/-$ mice. $a$, Comparative analysis of CNTFR- $\alpha, \operatorname{LIFR} \beta$, gp130, and CNTF in spinal cord of $c t-1+/+$ and $c t-1$ $-/-$ mice. The RT-PCR was performed with RandomHexamer primer amplified spinal cord RNA, and the signals were compared with $\beta$-actin signals from the same batches of cDNA. The relative intensities for CNTFR- $\alpha$, LIFR $\beta$, gp130, and CNTF mRNAs are shown on the left side. Values shown represent mean \pm SEM from at least three independent experiments. On the right, representative results from individual PCR reactions are shown. $b$, LIF mRNA levels in sciatic nerve from $c t-1+/+$ and $c t-1$ $-/-$ mice. Absolute levels of LIF mRNA were determined by use of a shortened competitor cRNA standard, which is identical with the LIF mRNA sequence except for an $81 \mathrm{bp}$ internal deletion (Sendtner et al., 1996). Data shown are mean \pm SEM from three independent experiments. A picture of a representative $1.5 \%$ agarose gel showing the PCR amplification products is shown on the right side. $c$, CNTF mRNA levels in sciatic nerve from $c t-1+/+$ and $c t-1-/-$ mice. The relative intensity of CNTF mRNAs conferred to $\beta$-actin signals were determined as described in $a$. Values shown are mean \pm SEM from three independent experiments.
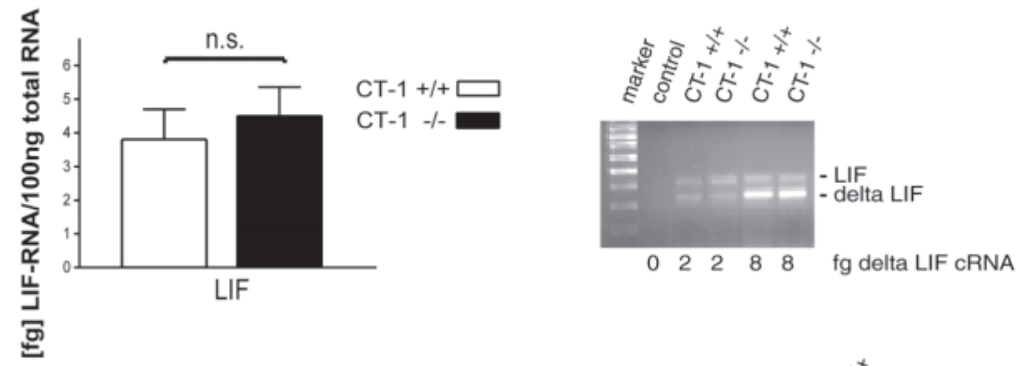

C

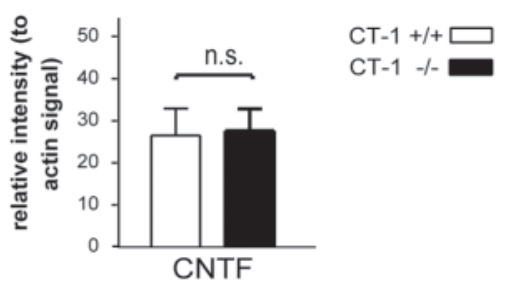

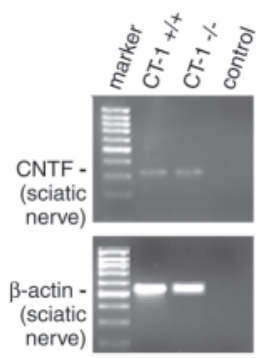

Expression of, CNTFR- $\alpha$, LIFR $\beta$, gp130, CNTF, and LIF in $\mathrm{ct}-1+1+$ and ct-1 - /- mice. CNTFR- $\alpha$, LIFR $\beta$, gp130, and CNTF mRNA levels were determined with semiquantitative RT-PCR tests that were standardized to $\beta$-actin mRNA. DNase-treated total RNA from spinal cord or sciatic nerve was used, and the RT reaction was performed with random hexamer primers according to the manufacturer's recommendations (Life Technologies, Karlsruhe, Germany). The primer combinations used for the individual receptor PCRs were: for CNTFR- $\alpha$ forward 5'-CAAGGTCTC-CATAAGTGTCAGC-3'; reverse 5'-GTCACTCCAT-GTCCCAAT- CTCA-3' (product size: $354 \mathrm{bp}$ ); LIFR $\beta$ : forward 5'-CAG-TTTCAGCCAGGAGTAAGAT-3'; reverse 5'-GGTCAGCAATTCTCAGTGT-CTT-3' (product size: 334 bp); gp130: forward 5'-CGCAGTCAAAG-TCCGTCTCACA3'; reverse 5'-GCTTCATTTTTCCCCACTT TCT-3' (product size: 492 bp); CNTF: forward 5'-GAGCAATCACCTCTGACCCTT-3'; reverse 5'CAGGCTGGATCAAGACAGTAAG-3' (product size: 321 bp). The PCRs were performed for 30 and 35 cycles with $95^{\circ} \mathrm{C}$ for $30 \mathrm{sec}, 58^{\circ} \mathrm{C}$ for $30 \mathrm{sec}$, and $72^{\circ} \mathrm{C}$ for $30 \mathrm{sec}$. The primers used for the PCR amplification of $\beta$-actin were the following: forward 5'-GTGGGCCGCCCTAGGCACCAG-3'; reverse 5'-CTCTTTAATGTCACGCACGATT- TC-3' (product size: 539 bp on cDNA level and $1090 \mathrm{bp}$ on genomic DNA level). The $\beta$-actin PCR was performed for 30 and $35 \mathrm{cycles}$ with $95^{\circ} \mathrm{C}$ for $30 \mathrm{sec}, 58^{\circ} \mathrm{C}$ for $30 \mathrm{sec}$, and $72^{\circ} \mathrm{C}$ for $90 \mathrm{sec}$.

For analysis of LIF expression, a quantitative RT-PCR test was performed with total RNA from sciatic nerve from $c t-1+/+$ and $c t-1-/-$ mice. The RT reaction and subsequent $\mathrm{PCR}$ amplification were performed in the presence of a shortened LIFR cRNA, as described (Sendtner et al., 1996). We have used 2, 4, and $8 \mathrm{fg}$ of the shortened LIF cRNA standard for estimation of LIF mRNA levels in the sciatic nerve.

RT-PCR products were evaluated with the AIDA software (Raytest, Straubenhardt, Germany). The data were analyzed with the GraphPad software (San Diego, CA).

Calculation and statistics. Single estimations (percentage of surviving neurons relative to the number of originally plated cells in individual wells) from independent experiments were pooled, and the results were expressed as mean and SEM. Statistical significance of differences was assessed by ANOVA followed by Bonferoni's test using the GraphPad Prism software.

\section{RESULTS}

\section{CT-1 supports embryonic chick and mouse motoneurons in vivo}

CT-1 is a potent survival factor for isolated embryonic rat (Pennica et al., 1996), mouse (Arce et al., 1999), and chick motoneurons. To characterize the effect of CT-1 on embryonic motoneurons in vivo, the factor was applied daily onto the chorioallantoic membrane of developing chick embryos (Fig. $1 A$ ) between embryonic days 5 and 9. CT-1 has a modest but significant effect on survival of lumbar 

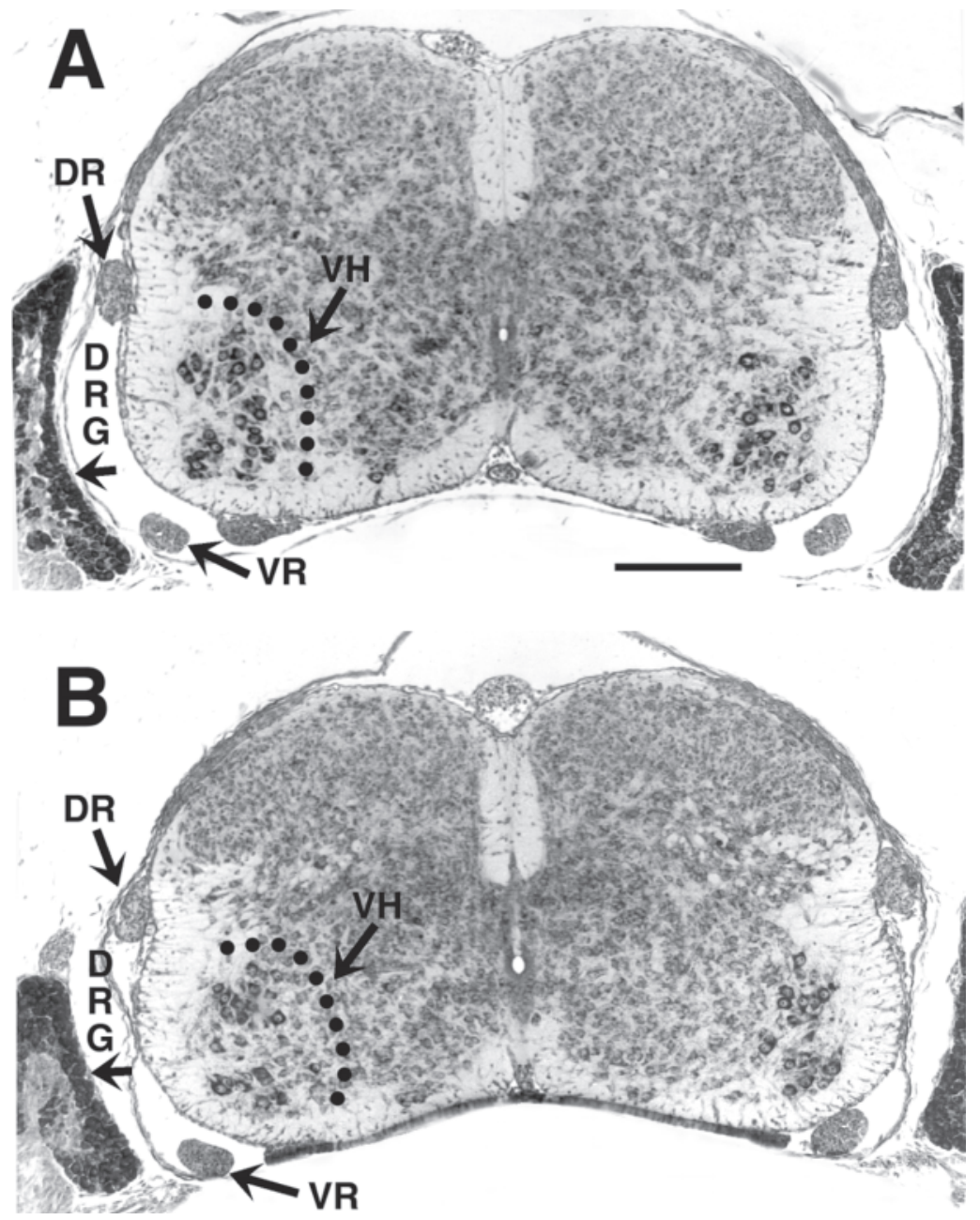

Figure 5. Transverse sections of the lumbar spinal cord from P1 wild-type $(A)$ and $c t-1-/-$ homozygous $(B)$ mice. $D R$, Dorsal root; $D R G$, dorsal root ganglion; $V H$, ventral horn; $V R$, ventral root. Except for the presence of fewer MNs, the homozygous spinal cord is indistinguishable from the wild-type control. Scale bar, $75 \mu \mathrm{m}$. motoneurons at daily doses of 5 or $10 \mu \mathrm{g}$. The effect of CT-1 treatment at $10 \mu \mathrm{g} / \mathrm{d}$ was lower than the rescue effect of muscle extract (Fig. $1 A$ ), suggesting that CT-1 acts on subpopulations of motoneurons and thus does not support the survival of all motoneurons that undergo cell death during this critical development period. Similarly, CT-1, at optimal concentrations, support only $\sim 50 \%$ of isolated lumbar chick spinal motoneurons in culture, which is significantly lower $(p<0.02)$ than the effect of muscle extract in the same cultures (Fig. 1B).

We have also tested the effects of a single CT- 1 injection into the uterus of pregnant mice at day 14 after conception. The embryos were isolated on day 18.5, and the number of motoneurons was determined in serial sections of the lumbar spinal cord. Similarly as observed in chick embryos, the extent of naturally occurring loss of motoneurons was significantly reduced by the CT-1 treatment (Table 1), indicating that developing mouse motoneurons can also respond to CT-1 treatment in vivo.

\section{Characterization of a CT-1-responsive subpopulation of mouse spinal motoneurons}

To characterize the subpopulation of CT-1-responsive motoneurons in more detail, we have isolated motoneurons from the lumbar spinal cord of 14-d-old mouse embryos and compared survival of these cells in the presence of CNTF, LIF, CT-1, or a combination of these factors. After $5 \mathrm{~d}$ in culture, CT-1 supported the survival of $45.8 \pm$ $4.2 \%$ of the initially plated motoneurons (Fig. 2). Survival rates were similar to previously reported values for embryonic rat motoneurons
(Pennica et al., 1996). CNTF and LIF supported the survival of $43.7 \pm 4.0$ and $52.6 \pm 3.6 \%$, respectively, of isolated E14 mouse motoneurons. Whereas the combination of CNTF and LIF did not show any additive effects (51.8 $\pm 3.8 \%$ survival), CT-1-mediated survival was significantly enhanced when LIF $(63.7 \pm 2.0 \%)$ or CNTF were added $(60.8 \pm 2.7 \%)$ together with this factor. The combination of CT-1, CNTF, and LIF does not enhance motoneuron survival beyond the levels observed with combinations of CT1-CNTF or CT-1-LIF. Similarly, the combination of CT-1 with BDNF or GDNF supported significantly more motoneurons than BDNF or GDNF alone. This indicates that subpopulations of motoneurons exist that respond to CT-1 but not to CNTF and/or LIF, and that the population of motoneurons in the E14 mouse spinal cord expressing the CNTFR $\alpha$ does not fully overlap with the population of motoneurons expressing the putative CT-1R $\alpha$.

\section{Generation of ct-1-deficient mice}

To characterize the subpopulations of motoneurons that physiologically depend on CT-1 in vivo, the corresponding gene was inactivated by homologous recombination in embryonic stem cells. A region from the EcoRI site within exon 1 and the SfII site in exon 3 was deleted from the genomic clone which was used for generation of the targeting vector and replaced by a Neomycin resistance cassette (Fig. 3A). This targeting strategy deletes the coding region from exon 1 to exon 3 . Heterozygous embryonic stem cell clones were identified, and heterozygous mice carrying the mutation were generated by standard knock-out techniques. The heterozygous 


\begin{tabular}{|c|c|c|c|c|}
\hline Age & WT & $c t-1-/-$ & & \\
\hline \multicolumn{5}{|c|}{ Lumbar motoneurons (L1-6) } \\
\hline E13.5 & $4713 \pm 389(n=3)$ & $4534 \pm 62(n=4)$ & NS & $-4 \%$ \\
\hline E14.5 & $3819 \pm 517(n=6)$ & $3603 \pm 361(n=6)$ & NS & $-6 \%$ \\
\hline $\mathrm{P} 1$ & $2151 \pm 58(n=13)$ & $1662 \pm 84(n=12)$ & $p<0.05$ & $-23 \%$ \\
\hline P9 & $2125 \pm 339(n=8)$ & $1576 \pm 148(n=8)$ & $p<0.005$ & $-26 \%$ \\
\hline \multicolumn{5}{|c|}{ Thoracic motoneurons (T2) } \\
\hline $\mathrm{P} 1$ & $232 \pm 12(n=5)$ & $165 \pm 16(n=5)$ & $p<0.01$ & $-29 \%$ \\
\hline P9 & $316 \pm 31(n=7)$ & $178 \pm 27(n=7)$ & $p<0.002$ & $-43 \%$ \\
\hline \multicolumn{5}{|c|}{ Brachial motoneurons } \\
\hline $\mathrm{P} 1$ & $1905 \pm 285(n=4)$ & $1335 \pm 205(n=4)$ & $p<0.02$ & $-30 \%$ \\
\hline P9 & $2371 \pm 139(n=7)$ & $1415 \pm 172(n=7)$ & $p<0.001$ & $-40 \%$ \\
\hline
\end{tabular}

NS, Not significant.

mice were back-crossed with $\mathrm{C} 57 / \mathrm{Bl6}$ mice. $C t-1-/-$ and $c t-1+/+$ mice used in this study were obtained from $c t-1+/-$ parents of the C57/Bl6 background or from F1 generation $c t-1-/-$ and $c t-1+/+$ mice from these $c t-1+/-$ mice on $\mathrm{C} 57 / \mathrm{Bl} 6$ background.

Ct-1-deficient mice are viable at birth and indistinguishable with respect to body weight, respiratory parameters, movement, and other behavioral characteristics from wild-type mice. During postnatal life, no obvious abnormalities are detectable up to 1 year. To show that $c t-1$ is not expressed as a truncated gene product in these mice, in situ hybridization was performed on sections from E13.5 WT and $c t-1-/-$ mice (Fig. $3 B$ ). Probes covering exon 1 and 2 and a 3'untranslated region of the $c t-1$ gene (Pennica et al., 1996) which is deleted by the homologous recombination, showed that mice homozygous for this mutation did not express CT-1.

\section{Expression of CNTF receptor components, CNTF and LIF in ct-1-deficient mice}

We have investigated the relative expression levels of gp130, LIFR $\beta$, and CNTFR $\alpha$ mRNA in the spinal cord of 3-month-old $c t-1+/+$ and $c t-1-/-$ mice (Fig. 4). In addition, CNTF mRNA levels in spinal cord (Fig. 4a) and sciatic nerve (Fig. 4c) and LIF mRNA levels in sciatic nerve (Fig. $4 b$ ) were determined. Our data indicate that lack of CT-1 does not lead to changes in expression of receptor components for CNTF and LIF, nor does it alter expression of CNTF and LIF in sciatic nerve of postnatal mice.

\section{Enhanced loss of motoneurons in the spinal cord and brainstem motor nuclei of ct-1-deficient mice occurs between embryonic day 13 and birth}

Measurement of grip strength in 4-month-old $c t-1-/-$ mice revealed a significant reduction of muscle strength in comparison to wild-type controls ( $c t-1-/-$ mice, $0.79 \pm 0.02 \mathrm{~N}, n=6$; wild-type mice, $0.96 \pm 0.01 \mathrm{~N}, n=4, p<0.0005)$. However, this loss of muscle strength did not lead to any other obvious behavioral impairments in these mice.ct-1-deficient mice could be inbred and produced viable offspring.

Histological analysis of 13- to 14-d-old control and ct-1 -/embryos revealed normal motoneuron numbers in the lumbar spinal cord. Similarly, the number of motoneurons in the facial nucleus of 15-d-old $c t-1-/-$ embryos was normal. However, motoneuron loss during the subsequent period of naturally occurring cell death was enhanced in the lumbar spinal cord (Fig. 5) by 23 and $26 \%$ at postnatal days 1 (P1) and 9, respectively (Table 2). In the thoracic spinal cord, motoneuron loss was enhanced by $29 \%$ at birth and by $>40 \%$ at postnatal day 9 . Similar loss of motoneurons was observed in the brachial spinal cord (Table 2).

\begin{tabular}{|c|c|c|c|}
\hline Age & WT & $c t-1-1-$ & \\
\hline \multicolumn{4}{|c|}{ Facial motoneurons } \\
\hline E15 & $6939 \pm 479(n=12)$ & $7377 \pm 265(n=4)$ & NS \\
\hline $\mathrm{P} 1$ & $4265 \pm 43(n=12)$ & $3223 \pm 92(n=11)^{*}$ & $-24 \%$ \\
\hline P9 & $3715 \pm 154(n=6)$ & $2903 \pm 188(n=5)^{*}$ & $-22 \%$ \\
\hline 4 weeks & $3115 \pm 120(n=7)$ & $2486 \pm 110(n=6)^{*}$ & $-20 \%$ \\
\hline 3 months & $2785 \pm 113(n=3)$ & $2345 \pm 40(n=3)^{*}$ & $-16 \%$ \\
\hline 6 months & $2802 \pm 255(n=4)$ & $2059 \pm 87(n=5)^{*}$ & $-17 \%$ \\
\hline \multicolumn{4}{|c|}{ Hypoglossal motoneurons } \\
\hline P1 & $1309 \pm 83(n=4)$ & $1005 \pm 46(n=4)^{*}$ & $-23 \%$ \\
\hline P9 & $1480 \pm 53(n=5)$ & $1143 \pm 69(n=5)^{*}$ & $-23 \%$ \\
\hline
\end{tabular}

${ }^{*} p<0.05$, as determined by two-tailed unpaired $t$ test. Variances were tested by $F$ test.

Enhanced loss of motoneurons was also detectable in brainstem motor nuclei (Table 3). In newborn and in 9-d-old postnatal mice, motoneuron numbers in the facial and hypoglossal nuclei were $20-25 \%$ lower than in wild-type controls. Interestingly, no further loss of motoneurons could be observed at later stages of postnatal development. In this respect, ct-1-deficient mice differ from CNTF-deficient mice, in which loss of motoneurons was not detectable in the facial nucleus until 6 months of age (Masu et al., 1993). Sensory neurons in the L4 dorsal root ganglion on P9 were unaffected in $c t-1-/-$ mice (control, $4789 \pm 215, n=5$ vs $c t-1-/-$, $5018 \pm 406, n=5)$.

\section{Motoneuron cell death after facial nerve transection is not enhanced in ct-1-deficient mice}

To investigate whether CT-1 plays a similar role in the maintenance of axotomized motoneurons in adult mice as CNTF and LIF, the facial nerve was transected in 4-week-old mice, and survival of motoneurons was determined 2 weeks later by counting motoneuron cell bodies in the facial nuclei both on the lesioned and unlesioned side (Fig. 6). In ct-1 KO mice, $86 \pm 5 \%$ of the motoneurons survived after nerve lesion, compared with $95 \pm 7 \%$ in wild-type mice (Table 4). This difference was not statistically significant. Similar results were obtained when the lesion was performed at 3 or 6 months (data not shown), suggesting that lack of CT-1 does not lead to enhanced loss of motoneurons after axotomy.

\section{DISCUSSION}

The CNTF-LIF family of neurotrophic cytokines includes at least four proteins that can support motoneuron survival via receptor complexes involving gp130 and LIFR $\beta$ (Gearing et al., 1987; Stöckli 

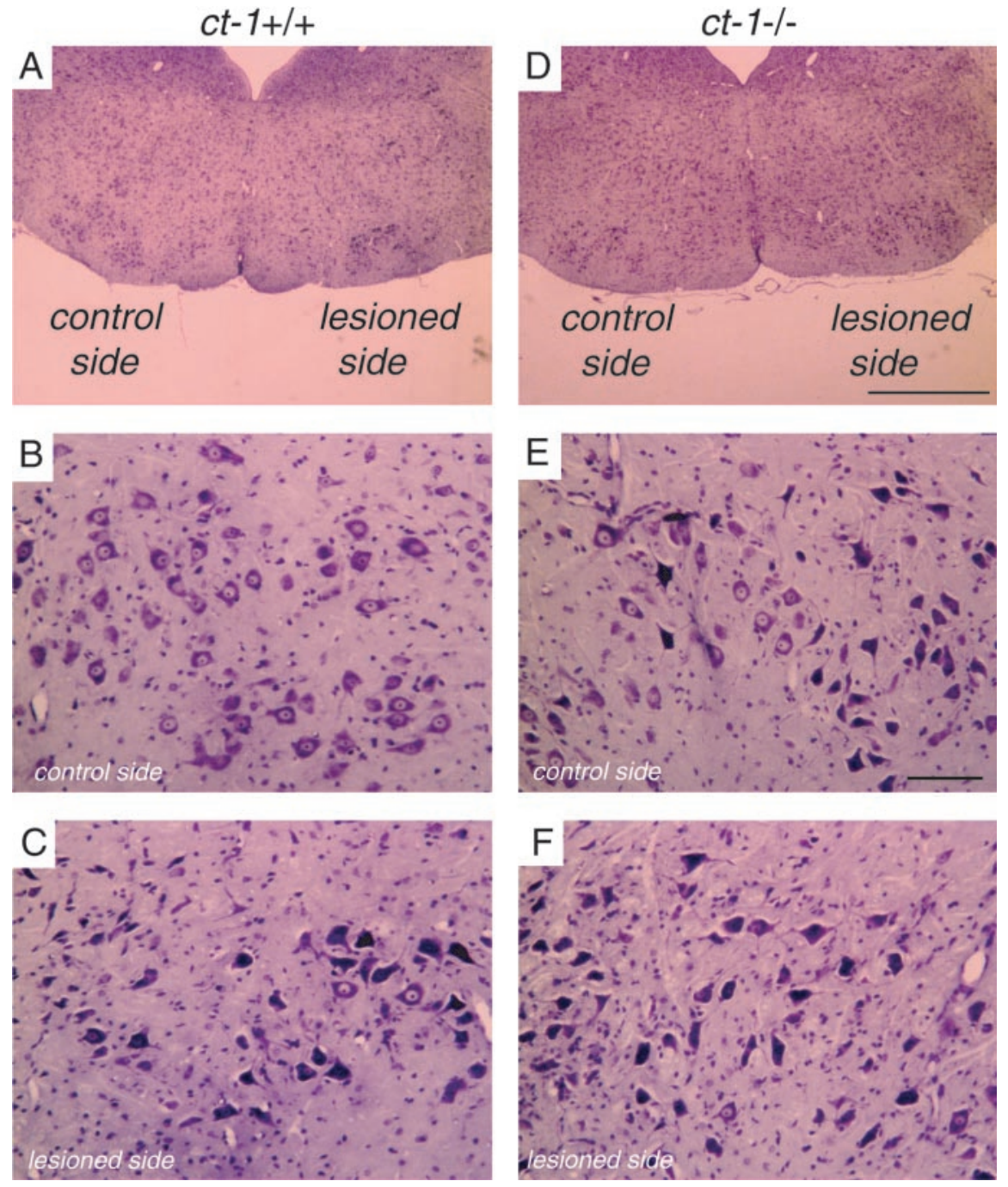

Figure 6. Morphology of the facial nuclei in postnatal day 42 wild-type and $c t-1-/-$ mice. In these mice, the facial nerve was transected on postnatal day 28. Mice were perfused, brainstem serial sections were prepared, and the motoneurons were analyzed 2 weeks after the lesion. $A$ and $D$ show the brainstem containing both facial nuclei in $c t-1+/+(A)$ and $c t-1-/-(D)$ mice; $B$ and $E$ show the unlesioned side of $c t-1+/+$ and $c t-1-/-$ mice at higher magnification; $C$ and $F$ the lesioned side. Scale bars: $A, D$, (shown in $D$ ), $1 \mathrm{~mm} ; B, C, E, F$, (shown in $E$ ), $100 \mu \mathrm{m}$.
Table 4. Facial nerve lesion in $c t$-1-deficient mice does not lead to enhanced loss of motoneurons

\begin{tabular}{llll} 
& Lesioned side & Control side & Percent survival \\
\hline WT $(n=5)$ & $2845 \pm 210$ & $3210 \pm 124$ & $95 \pm 7^{*}$ \\
$c t-1-/-(n=4)$ & $2180 \pm 179$ & $2505 \pm 120$ & $86 \pm 5^{*}$ \\
\hline
\end{tabular}

*Not significant.

et al., 1989; Pennica et al., 1995; Senaldi et al., 1999; Shi et al., 1999). Among these molecules, CNTF and LIF are the best characterized, whereas the physiological function of CT-1 and the recently discovered cardiotrophin-like cytokine (CLC)-novel neurotrophin (NNT-1) (Elson et al., 2000) for motoneurons is largely unknown. CT-1 resembles CNTF by the lack of a hydrophobic signal peptide. Thus, CT-1 cannot be released via a conventional secretory pathway from synthesizing cells. However, experiments with cultured myotubes have shown that a significant proportion of CT-1 produced by these cells is found in the culture medium (Pennica et al., 1996). This suggests that the factor might be released by an unconventional mechanism and thus be available to responsive cells. Our finding that developmental motoneuron survival is reduced in ct-1-deficient mice suggests that CT-1, despite the lack of a secretory signal peptide, is released from muscle cells and plays a physiological role for these neurons during a critical period of development. Thus, cardiotrophin-1 is the only ligand acting on gp130/LIFR heterodimeric receptors that appears to be physiologically required for the survival of motoneurons during embryonic development.

CT-1, in contrast to CNTF, is produced at relatively high levels in the embryonic limb bud (Pennica et al., 1996) and thus could act as a target-derived neurotrophic factor on responsive motoneurons. Skeletal muscle is considered as the most important source of trophic support for embryonic motoneurons. In the chick embryo, removal of a limb bud results in massive loss of innervating motoneurons (Hamburger, 1934, 1975; Oppenheim, 1981; Burek and Oppenheim, 1996; Caldero et al., 1998). Ablation of skeletal muscle by genetic manipulation in mice results in virtually complete loss of motoneurons between embryonic day 14 and birth (Grieshammer et al., 1998). These results underline the importance of skeletal muscle for motoneurons during this critical period of development.

The first evidence on the identity of CNTF family members that might be involved in this process was from mice in which receptor components were deleted by homogenous recombination. Developmental cell death of spinal and brainstem motoneurons is enhanced in mice lacking gp130 (Nakashima et al., 1999), LIFR $\beta$ (Li et al., 1995), or CNTFR $\alpha$ (DeChiara et al., 1995). Thus, members of the CNTF-LIF family of neurotrophic cytokines seem to be involved as modulators of motoneuron survival during this critical period of development. However, ablation of the genes for CNTF and/or LIF 
does not result in enhanced death of developing motoneurons (Masu et al., 1993; Sendtner et al., 1996). By contrast, deficiency of CNTF and the combined lack of CNTF and LIF result in enhanced postnatal loss of motoneurons. This reflects the observation that CNTF expression in Schwann cells is only found postnatally (Sendtner et al., 1992) and that significant quantities of LIF are only produced in Schwann cells after nerve lesion in adult rodents (Banner and Patterson, 1994; Curtis et al., 1994). CNTF and LIF are not expressed in significant quantities by skeletal muscle. Therefore, the observation that CNTFR $\alpha$-deficient mice show a similar loss of motoneurons as LIFR $\beta$ or even gp130-deficient mice suggests the presence of additional factors that act through $\operatorname{CNTFR} \alpha, \operatorname{LIFR} \beta$, and gp130 on developing motoneurons. However, even in mice lacking these receptor components, the loss of motoneurons in brainstem nuclei and the spinal cord is in the range of $40 \%$ and thus much lower than in mice in which skeletal muscle was removed (Grieshammer et al., 1998), suggesting that additional target-derived factors are involved that act via independent receptors and thus support survival of motoneurons (Henderson et al., 1998; Oppenheim, 1996a). Furthermore, these data indicate that subpopulations of motoneurons might differ in their requirement for specific survival factors during development.

The survival of isolated motoneurons in culture is enhanced when factors from skeletal muscle and Schwann cells are added in combination (Arce et al., 1998). For example, CT-1 and GDNF act synergistically when added together to isolated spinal motoneurons from rat embryos. However, when combinations of factors acting via shared receptor components such as CNTF and LIF or BDNF and neurotrophin-4 (NT-4) (Hughes et al., 1993) are tested at saturating concentrations, additive effects are not observed. However, such culture conditions do not necessarily reflect the physiological situation in vivo, where the availability of each of these factors might be limited. Indeed, mice in which two ligands from the same gene family such as CNTF and LIF (Sendtner et al., 1996) or BDNF and NT-4 (Conover et al., 1995; Liu et al., 1995) are inactivated show a more severe loss of neurons than the single knock-out animals.

However, recent evidence suggests that such data may not necessarily reflect redundancy. Neurons from mice in which the Shcbinding site of the trkB receptor is mutated show a differential response to NT-4 and BDNF (Minichiello et al., 1998). Moreover, the finding that the expression of members of the same gene family such as BDNF and NT-4 are differentially regulated in skeletal muscle (Funakoshi et al., 1993, 1995; Griesbeck et al., 1995) suggests a differential role of these factors for subtypes of motoneurons. We have shown that the subpopulation of motoneurons that can be supported by CNTF only partially overlaps with CT-1-responsive motoneurons. Moreover, the extent of motoneuron loss observed in $c t$-1-deficient mice is less than that in LIFR $\beta$ (Li et al., 1995), gp130 (Nakashima et al., 1999), or even CNTFR $\alpha$-deficient mice (Conover et al., 1995). Thus, CT-1 appears to be a specific muscle-derived neurotrophic factor for a subpopulation of embryonic motoneurons. It will be interesting to determine whether the recently identified CNTF family member, CLC/NNT (Senaldi et al., 1999; Shi et al., 1999b), acts together with CT-1 in regulating motoneuron survival during embryonic development.

An important difference between CNTF and CT-1-deficient mice is the time course when motoneuron loss occurs. In both CNTFdeficient mice and CNTF-LIF double knock-out mice, enhanced loss of motoneurons was not detectable during embryonic development (Masu et al., 1993; Sendtner et al., 1996). Motoneuron degeneration in these mice was only detectable after birth, and enhanced motoneuron cell death was observed in particular when motoneu- rons were axotomized in CNTF-LIF double-deficient mice at an age of 4 weeks or later. In contrast, motoneuron loss in the facial nucleus of CT-1-deficient mice after axotomy did not differ from controls at 2 or 6 months. This suggests that CT-1, which is predominantly expressed in skeletal muscle, does not act as a lesion factor for supporting the survival of axotomized motoneurons after birth. In contrast, CNTF, which is physiologically expressed at relatively high quantities in Schwann cells (Stöckli et al., 1989, 1991; Rende et al., 1992), and LIF, which is produced at significant levels in Schwann cells after nerve lesion (Banner and Patterson, 1994; Curtis et al., 1994), apparently act together to support survival of lesioned postnatal motoneurons (Sendtner et al., 1996). Thus, CT-1 differs significantly from CNTF and LIF and, with the possible exception of HGF-SF (Yamamoto et al., 1997; Novak et al., 2000), seems to be the first classical target-derived neurotrophic factor for motoneurons identified so far that acts physiologically in vivo on a subpopulation of developing motoneurons during the critical period of naturally occurring cell death.

\section{REFERENCES}

Arakawa Y, Sendtner M, Thoenen H (1990) Survival effect of ciliary neurotrophic factor (CNTF) on chick embryonic motoneurons in culture: Comparison with other neurotrophic factors and cytokines. J Neurosci 10:3507-3515.

Arce V, Pollock RA, Philippe JM, Pennica D, Henderson CE, deLapeyriere O (1998) Synergistic effects of Schwann- and muscle-derived factors on motoneuron survival involve GDNF and cardiotrophin-1 (CT-1). J Neurosci 18:1440-1448.

Arce V, Garces A, de Bovis B, Filippi P, Henderson C, Pettmann B, deLapeyriere O (1999) Cardiotrophin-1 requires LIFRbeta to promote survival of mouse motoneurons purified by a novel technique. J Neurosci Res 55:119-126.

Banner LR, Patterson PH (1994) Major changes in the expression of the mRNAs for cholinergic differentiation factor/leukemia inhibitory factor and its receptor after injury to adult peripheral nerves and ganglia. Proc Natl Acad Sci USA 91:7109-7113.

Becker E, Soler RM, Yuste VJ, Gine E, Sanz-Rodriguez C, Egea J, MartinZanca D, Comella JX (1998) Development of survival responsiveness to brain-derived neurotrophic factor, neurotrophin 3 and neurotrophin $4 / 5$, but not to nerve growth factor, in cultured motoneurons from chick embryo spinal cord. J Neurosci 18:7903-7911.

Bloch-Gallego E, Huchet M, El M'Hamdi H, Xie F-K, Tanaka H, Henderson CE (1991) Survival in vitro of motoneurons identified or purified by novel antibody-based methods is selectively enhanced by muscle-derived factors. Development 111:221-232.

Burek MJ, Oppenheim RW (1996) Programmed cell death in the developing nervous system. Brain Pathol 6:427-446.

Caldero J, Prevette D, Mei X, Oakley RA, Li L, Milligan C, Houenou L, Burek M, Oppenheim RW (1998) Peripheral target regulation of the development and survival of spinal sensory and motor neurons in the chick embryo. J Neurosci 18:356-370.

Calof AL, Reichardt LF (1984) Motoneurons purified by cell sorting respond to two distinct activities in myotube-conditioned medium. Dev Biol 106:194-210.

Clarke PG, Oppenheim RW (1995) Neuron death in vertebrate development: in vitro methods. Methods Cell Biol 46:277-321.

Conover JC, Erickson JT, Katz DM, Bianchi LM, Poueymirou WT, McClain J, Pan L, Helgren M, Ip NY, Boland P, Friedman B, Wiegand S, Vejsada R, Kato AC, DeChiara TM, Yancopoulos GD (1995) Neuronal deficits, not involving motor neurons, in mice lacking BDNF and/or NT4. Nature 375:235-238.

Curtis R, Scherer SS, Somogyi R, Adryan KM, Ip NY, Zhu Y, Lindsay RM, Distefano PS (1994) Retrograde axonal transport of LIF is increased by peripheral nerve injury: Correlation with increased LIF expression in distal nerve. Neuron 12:191-204.

DeChiara TM, Vejsada, R, Poueymirou WT, Acheson A, Suri C, Conover JC, Friedman B, McClain J, Pan L, Stahl N, Ip NY, Kato A, Yancopoulos GD (1995) Mice lacking the CNTF receptor, unlike mice lacking CNTF, exhibit profound motor neuron deficits at birth. Cell 83:313-322.

Dohrmann U, Edgar D, Sendtner M, Thoenen H (1986) Muscle-derived factors that support survival and promote fiber outgrowth from embryonic chick spinal motor neurons in culture. Dev Biol 118:209-221.

Ebens A, Brose K, Leonardo ED, Hanson MGJ, Bladt F, Birchmeier C, Barres BA, Tessier-Lavigne M (1996) Hepatocyte growth factor/scatter factor is an axonal chemoattractant and a neurotrophic factor for spinal motor neurons. Neuron 17:1157-1172.

Elson GC, Lelievre E, Guillet C, Chevalier S, Plun-Favreau H, Froger J, 
Suard I, de Coignac AB, Delneste Y, Bonnefoy JY, Gauchat JF, Gascan $\mathrm{H}$ (2000) CLF associates with CLC to form a functional heteromeric ligand for the CNTF receptor complex. Nat Neurosci 3:867-872.

Ericson J, Thor S, Edlund T, Jessell TM, Yamada T (1992) Early stages of motor neuron differentiation revealed by expression of homeobox gene Islet-1. Science 256:1555-1560.

Escary J-L, Perreau J, Duménil D, Ezine S, Brûlet P (1993) Leukaemia inhibitory factor is necessary for maintenance of haematopoietic stem cells and thymocyte stimulation. Nature 363:361-364.

Funakoshi H, Frisen J, Barbany G, Timmusk T, Zachrisson O, Verge VMK, Persson H (1993) Differential expression of mRNAs for neurotrophins and their receptors after axotomy of the sciatic nerve. J Cell Biol 123:455-465.

Funakoshi H, Belluasdo N, Arenas E, Yamamoto Y, Casabona A, Persson H, Ibanez CF (1995) Muscle-derived Neurotrophin-4 as an activitydependent trophic signal for adult motor neurons. Science 268:1495-1499.

Garcès A, Haase G, Airaksinen MS, Livet J, Filippi P, deLapeyière O (2000) GFR $\alpha 1$ is required for development of distinct subpopulations of motoneuron. J Neurosci 20:4992-5000.

Gearing DP, Gough NM, King JA, Hilton DJ, Nicola NA, Simpson RJ, Nice EC, Kelso A, Metcalf D (1987) Molecular cloning and expression of cDNA encoding a murine myeloid leukaemia inhibitory factor (LIF). EMBO J 6:3995-4002.

Griesbeck O, Parsadanian ASh, Sendtner M, Thoenen H (1995) Expression of neurotrophins in skeletal muscle: quantitative comparison and significance for motoneuron survival and maintenance of function. J Neurosci Res 42:21-33.

Grieshammer U, Lewandoski M, Prevette D, Oppenheim RW, Martin GR, Pettmann B, Henderson CE (1998) Muscle-specific cell ablation conditional upon Cre-mediated DNA recombination in transgenic mice leads to massive spinal and cranial motoneuron loss Neuronal cell death. Neuron 20:633-647.

Hamburger V (1934) The effects of wing bud extirpation on the development of the central nervous system in chick embryos. J Exp Zool 68:449-494.

Hamburger V (1975) Cell death in the development of the lateral column of the chick embryo. J Comp Neurol 160:535-546.

Hanson Jr MG, Shen S, Wiemelt AP, McMorris FA, Barres BA (1998) Cyclic AMP elevation is sufficient to promote the survival of spinal motor neurons in vitro. J Neurosci 18:7361-7371.

Henderson CE (1996) Role of neurotrophic factors in neuronal development. Curr Opin Neurobiol 6:64-70.

Henderson CE, Phillips HS, Pollock R A, Davies AM, Lemeulle C, Armanini M, Simpson LC, Moffet B, Vandlen RA, Koliatsos VE, Rosenthal A (1994) GDNF: a potent survival factor for motoneurons present in peripheral nerve and muscle. Science 266:1062-1064.

Henderson CE, Yamamoto Y, Livet J, Arce V, Garces A, deLapeyriere O (1998) Role of neurotrophic factors in motoneuron development. J Physiol (Paris) 92:279-281.

Houenou LJ, Li L, Lo AC, Yan Q, Oppenheim RW (1994) Naturally occurring and axotomy-induced motoneuron death and its prevention by neurotrophic agents: a comparison between chick and mouse. Prog Brain Res 102:217-226.

Hughes RA, Sendtner M, Thoenen H (1993) Members of several gene families influence survival of rat motoneurons in vitro and in vivo. J Neurosci Res 36:663-671.

Li M, Sendtner M, Smith A (1995) Essential function of LIF receptor in motor neurons. Nature 378:724-727.

Liu X, Ernfors P, Wu H, Jaenisch R (1995) Sensory but not motor neuron deficits in mice lacking NT4 and BDNF. Nature 375:238-240.

Masiakowski P, Liu H, Radziejewski C, Lottspeich F, Oberthuer W, Wong V, Lindsay RM, Furth ME, Panayotatos N (1991) Recombinant human and rat ciliary neurotrophic factors. J Neurochem 57:1003-1012.

Masu Y, Wolf E, Holtmann B, Sendtner M, Brem G, Thoenen H (1993) Disruption of the CNTF gene results in motor neuron degeneration. Nature 365:27-32.

McKay SE, Garner A, Caldero J, Tucker RP, Large T, Oppenheim RW (1996) The expression of trkB and p75 and the role of BDNF in the developing neuromuscular system of the chick embryo. Development 122:715-724.

Melton DA, Krieg PA, Rebagliati MR, Maniatis T, Zinn K, Green MR (1984) Efficient in vitro synthesis of biologically active RNA and RNA hybridization probes from plasmids containing a bacteriophage SP6 promoter. Nucleic Acids Res 12:7035-7056.

Milligan CE, Oppenheim RW, Schwartz LM (1994) Motoneurons deprived of trophic support in vitro require new gene expression to undergo programmed cell death. J Neurobiol 25:1005-1016.

Minichiello L, Casagranda F, Tatche RS, Stucky CL, Postigo A, Lewin GR, Davies AM, Klein R (1998) Point mutation in trkB causes loss of NT4dependent neurons without major effects on diverse BDNF responses. Neuron 21:335-345.

Nakashima K, Wiese S, Yanagisawa M, Arakawa H, Kimura N, Hisatsune T, Yoshida K, Kishimoto T, Sendtner M, Taga T (1999) Developmental requirement of gp130 signaling in neuronal survival and astrocyte differentiation. J Neurosci 19:5429-5434.

Novak KD, Prevette D, Wang S, Gould TW, Oppenheim RW (2000) Hepatocyte growth factor/scatter factor is a neurotrophic survival factor for lumbar but not for other somatic motoneurons in the chick embryo. J Neurosci 20: 326-337.

Oppenheim RW (1981) Neuronal cell death and some related regressive phenomena during neurogenesis: a selective historical review and progress report. In: Studies in developmental neurobiology, pp 74-133. (Cowan WM, ed). Oxford: Oxford UP.

Oppenheim RW (1996a) Neurotrophic survival molecules for motoneurons: an embarrassment of riches. Neuron 17:195-197.

Oppenheim RW (1996b) The concept of uptake and retrograde transport of neurotrophic molecules during development: history and present status. Neurochem Res 21:769-777.

Oppenheim RW, Haverkamp LJ, Prevette D, McManaman JL, Appel SH (1988) Reduction of naturally occurring motoneuron death in vivo by a target-derived neurotrophic factor. Science 240:919-921

Oppenheim RW, Prevette D, Qin-Wei Y, Collins F, MacDonald J (1991) Control of embryonic motoneuron survival in vivo by ciliary neurotrophic factor. Science 251:1616-1618

Oppenheim RW, Houenou LJ, Parsadanian AS, Prevette D, Snider WD, Shen L (2000) GDNF and developing mammalian motoneurons: regulation of programmed cell death among motoneuron subtypes. J Neurosci 20:5001-5011.

Pennica D, King KL, Shaw KJ, Luis E, Rullamas J, Luoh SM, Darbonne WC, Knutzon DS, Yen R, Chien KR, Baker JE, Wood WI (1995) Expression cloning of cardiotrophin 1, a cytokine that induces cardiac myocyte hypertrophy. Proc Natl Acad Sci USA 92:1142-1146.

Pennica D, Arce V, Swanson TA, Vejsada R, Pollock RA, Armanini M, Dudley K, Phillips HS, Rosenthal A, Kato AC, Henderson CE (1996) Cardiotrophin-1, a cytokine present in embryonic muscle, supports longterm survival of spinal motoneurons. Neuron 17:63-74.

Phillips HS, Hains JM, Laramee GR, Rosenthal A, Winslow JW (1990) Widespread expression of BDNF but not NT3 by target areas of basal forebrain cholinergic neurons. Science 250:290-294.

Rende M, Muir D, Rouslathi E, Hagg T, Varon S, Manthorpe M (1992) Immunolocalization of ciliary neuronotrophic factor in adult rat sciatic nerve. Glia 5:25-32.

Robledo O, Fourcin M, Chevalier S, Guillet C, Auguste P, PouplardBarthelaix A, Pennica D, Gascan H (1997) Signalling of the cardiotrophin-1 receptor. Evidence for a third receptor component. J Biol Chem 272:4855-4863.

Schnaar RL, Schaffner AE (1981) Separation of cell types from embryonic chicken and rat spinal cord: characterization of motoneuron-enriched fractions. J Neurosci 1:204-214.

Senaldi G, Varnum BC, Sarmiento U, Starnes C, Lile J, Scully S, Guo J, Elliott G, McNinch J, Shaklee CL, Freeman D, Manu F, Simonet WS, Boone T, Chang MS (1999) Novel neurotrophin-1/B cell-stimulating factor-3: a cytokine of the IL-6 family. Proc Natl Acad Sci USA 96:11458-11463

Sendtner M, Kreutzberg GW, Thoenen H (1990) Ciliary neurotrophic factor prevents the degeneration of motor neurons after axotomy. Nature 345:440-441.

Sendtner, M, Stöckli KA, Thoenen, H (1992) Synthesis and location of ciliary neurotrophic factor in the rat sciatic nerve of the adult rat after lesion and during regeneration. J Cell Biol 118:139-148.

Sendtner M, Götz R, Holtmann B, Escary J-L, Masu Y, Carroll P, Wolf E, Brehm G, Brulet P, Thoenen H (1996) Cryptic physiological trophic support of motoneurons by LIF disclosed by double gene targeting of CNTF and LIF. Curr Biol 6:686-694.

Shi Y, Wang W, Yourey PA, Gohari S, Zukauskas D, Zhang J, Ruben S, Alderson RF (1999) Computational EST database analysis identifies a novel member of the neuropoietic cytokine family. Biochem Biophys Res Commun 262:132-138.

Stewart CL, Kaspar P, Brunet LJ, Bhatt H, Gadi I, Kontgen F, Abbondanzo SJ (1992) Blastocyst implantation depends on maternal expression of leukaemia inhibitory factor. Nature 359:76-79.

Stöckli KA, Lottspeich F, Sendtner M, Masiakowski P, Carroll P, Götz R, Lindholm D, Thoenen H (1989) Molecular cloning, expression and regional distribution of rat ciliary neurotrophic factor. Nature 342:920-923.

Stöckli KA, Lillien LE, Naeher-Noe, M, Breitfeld, G, Hughes RA, Thoenen, H, Sendtner, M (1991) Regional distribution, developmental changes and cellular localization of CNTF-mRNA and protein in the rat brain. J Cell Biol 115:447-459.

Wiese S, Metzger F, Holtmann B, Sendtner M (1999) The role of p75 NTR in modulating neurotrophin survival effects in developing motoneurons. Eur J Neurosci 11:1668-1676.

Yamamoto Y, Livet J, Pollock RA, Garces A, Arce V, deLapeyriere O, Henderson CE (1997) Hepatocyte growth factor (HGF/SF) is a musclederived survival factor for a subpopulation of embryonic motoneurons. Development 124:2903-2913. 